\title{
Knowledge Management and Business Rescue in South Africa: A Systematic Literature Review
}

\author{
Andretta Tsebe ${ }^{1}$ \\ ${ }^{1}$ Specialist, Department of Public Enterprises, Pretoria, South Africa \\ Correspondence: Andretta Tsebe, South African Department of Public Enterprises, Pretoria, South Africa.
}

Received: December 10, 2021

Accepted: January 10, $2022 \quad$ Online Published: January 18, 2022

doi:10.5539/ibr.v15n2p46

URL: https://doi.org/10.5539/ibr.v15n2p46

\begin{abstract}
The business rescue law, in the South African Companies Act, No. 71 of 2008 was designed to alleviate the challenges facing distressed companies. The purpose of the paper is to provide a coherent synthesis of the systematic literature review on the incorporation of knowledge management into the business rescue practices in South Africa. Scholarly databases were searched to identify papers on knowledge management and business rescue in South Africa, which resulted in initial of 1961 papers. Exclusion criteria was applied, and it emerged that 12 papers were relevant for the study. Findings indicate the business rescue is a relatively new field in academic research and that there is a need to conduct further research on knowledge management pillars used in the business process by practitioners and the executives of distresses companies. The paper concludes that study findings can serve as guidance for improving practice notes and procedures in the industry.
\end{abstract}

Keywords: business rescue, turnaround, South Africa, knowledge management, systematic review

\section{Introduction}

In South Africa, the legal provisions regulating the registration and governance of both public and private companies anticipate the possibility of companies falling into financial distress for various reasons. The law provides guidance for executives and owners of companies on how to manage distress in the effort of either returning the company to prosperity or liquidation. The managing of financial distress is provided for, in Chapter 6 of the Companies Act, No. 71 of 2008, which allows companies to undertake the business rescue process, which can be a turnaround strategy.

The legal provisions for a business rescue or turnaround intervention in South Africa require the management of the distressed company to decide whether to follow the formal legislated route for a business rescue process as prescribed by Chapter 6 of the Companies Act 71 of 2008, or to adopt an in-house turnaround approach in a bid to return the company to viability, sustainability, and profitability. This is a similar approach to the Chapter 11 bankruptcy provisions offered in the United States of America as posited by Aviazian and Zhou (2012), and similarly by Walton, Umfreville and Jacobs (2020) on the utilisation of the Schedule B1 of the Insolvency Act of 1986 in the United Kingdom, aimed at giving distressed companies opportunities to restructure and turnaround.

It is often the case that application to the courts for business rescue is made only when insolvency is imminent and possibly unavoidable but by which time it may be too late to reverse the decline and rescue the business. Ngobeni (2016) indicates that it is imperative, that boards of directors and the executive management of companies recognize the signs of decline and imminent insolvency when they first become apparent before the decline or distress reaches the so-called 'point of no return' when it is still practically possible to reverse the business decline. According to Fair and Raymond (1993) and Paul (2010) for a business rescue intervention is to be effective, it is critically important for the business rescue practitioners and/or the executive management of the distressed company to address the actual causes of the distress rather than only the symptoms. These authors differentiate between what they refer to as the 'internal' and the 'external' causes of the decline or distress. They also refer to 'extraneous' causes of decline or distress as being those that are external to the organization itself.

It is in this context that Newton (2009), Shein (2011), and Finch (2012), argue that to determine the most appropriate rescue intervention and the extent of the effort that will be required to rescue a distressed company, it is important to gather information on the nature and extent of the distress, the fundamental causes, the extraneous forces are that are driving the decline or distress. In addition, how much time is left before the organization's 
decline or distress reaches the so-called 'point of no return' and closure due to insolvency becomes unavoidable.

These scholars sought to understand the causes and operational indicators of a company in distress within the context of strategic management within organizations. Given the link between business rescue and its relevance to business sustainability (Pretorius, 2008; Lebeloane, 2017), company executives need to foresee failures that can be fatal to the company, causing a deterioration in the market and ultimately leading to bankruptcy.

\subsection{Purpose of the Paper}

The purpose of this paper is to synthesize literature on a business rescue in South Africa and similar provisions available for turnaround of distressed businesses. Additionally, analyse the knowledge management practices used in the implementation of business rescue. Synthesizing existing research in this paper is important as to integrate and build a theoretical bridge between findings in literature on business rescue and address any gaps found in practice.

\subsection{Literature Review}

\subsubsection{Business Rescue}

The history of business rescue in South Africa, according to Wood (2007), can be traced back to the Dutch settlers who introduced the Insolvency Ordinance of Amsterdam. The British subsequently modified the Dutch insolvency law in 1829 and also instituted successive similar laws in the various republics of pre-Union South Africa. After the Anglo-Boer War and the formation of the union of South Africa in 1910, a new common solvency law was adopted in 1916, which included provisions from the preceding laws and was amended in 1936, after the Second World War. The 1936 Insolvency Act applied only to individuals, whereas the Insolvency Act of 1973 applied to business organizations and corporations, according to Wood (2007).

The Insolvency Act of 1936 defined insolvency as "a debtor whose estate is under sequestration and includes such as debtor before the sequestration of his estate", according to de Clercq Evans, Abrie, and Graham (2011). The liquidation of companies was originally governed by the Companies Act, No. 61 of 1973, which incorporated sections of the 1936 Insolvency Act. According to Pretorius (2008), Section 339 of the Companies Act (1973) articulates the provision of insolvency as "being applied Mutatis Mutandis in respect of any matter not specially provided for by this Act". Although the abovementioned Companies Act (1973) has been replaced by the Companies Act, No. 71 of 2008, the liquidation of companies is still governed by Chapter 14 of the Companies Act of 1973.

Beuthin and Luiz (2000), confirm that an application for insolvency of a company is made according to the provisions of the Companies Act of 1973 as well as the Insolvency Act of 1936, which require that:

(i) A company must be registered as a corporation,

(ii) An insolvent estate must be construed as a reference to a corporation; and

(iii) A special resolution for the voluntary winding-up of a company must be construed as a reference to a written resolution for the voluntary winding-up of a corporation in terms of the Act.

In this context, Pretorius, Delport, Havenga, and Vermaas (1991), explain that, in most cases, the winding-up of a business due to insolvency is done by the court on the grounds that the company is unable to pay its debt. Section 68 of the Companies Act of 1973 gives the courts the powers to wind-down a company if:

(i) The corporation is unable to pay its debts; or

(ii) The corporation has not commenced its business within a year from its registration or has suspended its business for a whole year; or

(iii) The members of the corporation who have more than one-half of the total number of votes have resolved in a meeting of members called for the winding-up and have signed a written resolution to that effect; and

(iv) It appears on application to the court to be just and equitable that the corporation is wound-up.

The court has the discretion to place a business under provisional sequestration and to invoke a rule nisi whereby it orders the interested parties to give written reasons why the business must not be fully sequestrated or closed down. According to de Clercq et al. (2011), this discretion of the court can be requested by a registered trade or labor union which represents the debtor's employees and by the employees themselves, for the recommendation of business rescue instead of company liquidation. 
The origins of business rescue in South Africa are found in the Companies Act, No. 71 of 2008, which offered companies a reprieve from liquidation in the aftermath of the global economic recession that was experienced at that time. According to the Companies Act (2008), business insolvency in South Africa is proscribed separately from business rescue.

The business insolvency process is governed by Sections 79 and 80 of the Companies Act (2008), as well as Chapter 14 of the Companies Act of 1973. Solvency and liquidity tests are prescribed and must be undertaken prior to embarking on a liquidation process. If a company is found to be solvent and able to pay its debts, it may however be liquidated in accordance with Sections 79 and 80 of the Companies of 2008. Section 80 of the Companies Act (2008) makes provision for solvent companies that choose to liquidate their assets voluntarily. However, if the company is found to be insolvent and is not able to pay its debt, Chapter 14 of the Companies Act of 1973 must be applied for the closure of the company. For insolvent companies, liquidation commences when the board of directors decides to apply for and register the liquidation application with the South African Companies Registration Office. Compulsory liquidation of solvent companies is done after the court has granted orders for the liquidation process to commence. As for voluntary liquidation, the process can commence once the decision of the company's board of directors has been registered with the South African Companies Registration Office for ratification. Once the assets of the imminently insolvent business have been sold, the company liquidator may apply for a certificate from the Master of the High Court, to terminate the process.

The business rescue process is also applicable to financially distressed companies which are defined in Section 128(f) of the Companies Act of 2008, as follows: "If it appears to be reasonably unlikely that the company will be able to pay its debts as they fall due and payable within the immediately ensuing six months" or "It appears to be reasonably likely that the company will become insolvent within the immediate ensuring six months".

Section 128(c) of the Companies Act of 2008, defines a business rescue process as a plan contemplated in Section 150 of the same act, which is aimed at rehabilitating or turning around the business. Similarly, Section 150 of the Companies Act (2008), defines a business rescue plan and requires that a business rescue plan must include at least:

(i) A complete list of all the material assets of the company, as well as an indication as to which assets were held as security by creditors when the business rescue proceedings began, and

(ii) A complete list of the creditors of the company when the business rescue proceedings began, as well as an indication as to which creditors would as secured, statutory preferment and concurrent in terms of the laws of insolvency, and an indication of which of the creditors have proved their claims.

The proposals that must be included in a business rescue plan are:

(i) The benefits of adopting the rescue plan as opposed to the benefits that would be received by creditors if the company were to be placed in liquidation, and

(ii) The effect that the business rescue plan will have on the holders of each class of the company's issued securities.

The assumptions and conditions in the business plan must include at least:

(i) The effect, if any, that the business rescue plan contemplates on the number of employees, and their terms and conditions of employment, and

(ii) The circumstances in which the business rescue plan will end.

The business rescue process is generally understood to be an instrument that provides legal certainty to companies that are facing bankruptcy. The Companies Act of 2008 articulates the business rescue process in three sections, which relate respectively to the commencement, investigation, and development of plans and recommendations for implementation. A business rescue process commences when an application is formally lodged in the court requesting reprieve for the company from its creditors. Should there be separate litigation against the company, the court's involvement in business rescue is limited to the commencement of the process.

In accordance with the provisions of the Companies Act of 2008, the business rescue proceedings must be implemented for a period of three months. A provision can be made to extend the duration of the business rescue by six to twenty-four months after the business rescue practitioner seeks support from the main creditors of the business. During the business rescue intervention, Mpofu, Nwafor and Selala (2018) explain that the appointed business rescue practitioner has full management control of the company. The Companies Act of 2008 specifies that during the business rescue process the company can apply for external funding for which it can use unsecured company assets as collateral. 
Section 153 of the Companies Act No. 71 of 2008 specifies that if a business rescue plan is adopted by the creditors and the board of directors of the company, then the company can continue to trade and the business rescue process will terminate. The termination of the process is resolved when the court sets aside the resolution to commence business rescue or converts the business rescue process into liquidation. The Companies Act of 2008 precludes any performance indicators that are related to the business rescue process. However, Section 154 of the Act states that once the business rescue plan is approved, it is binding on all creditors. Therefore, no claims for debt can be issued against the company once the business rescue process has begun. Nwafor (2017) argues that during business rescue proceedings, there are two types of moratoriums that can be placed on the creditors by the Act to reclaim any outstanding debt, with the aim of giving the distresses company space to restructure or turnaround its performance.

The business rescue process is important for South African companies that seek to avoid liquidation while involving all relevant parties in the re-organization of the company's future. The aim of the discussion that follows is to differentiate between the business rescue and turnaround strategies that can be used to support the legal provisions according to the Companies Act of 2008.

\subsubsection{Knowledge Management}

Knowledge management is one of the important pillars in organisations and industry practitioners. Harrington (2005) and Calitz and Cullen (2017) explain that knowledge management is a planned and continuous management of tolls, processes, systems and culture used to share, improve and use knowledge that is essential for decision making. The fundamental objective of knowledge management is to improve an organisation or industry effectiveness to disperse lessons and practice notes as part of continuous improvement efforts.

As distressed businesses under business rescue, there is a need for business rescue practitioners and company executives to develop effective knowledge management processes and strategies. In this respect, to ensure effective use of knowledge management, Bhatt (2001) and Byukusenge and Munene (2017) suggest that frameworks be built and implemented that focus:

(i) People who are responsible for information sharing and incorporation of past lessons into the DNA of the organization and industry.

(ii) Procedures and techniques that informs how the information will be dispersed in the business.

(iii) Technology and innovation that underpin the information sharing procedures in the business and to the practitioners in the industry.

(iv) Culture of information sharing in the industry and improving the rescue processes.

Studies by Pretorius and Rosslyn-Smith (2014), Le Roux and Pretorius (2017) and Rajaram and Singh (2018) made observations on knowledge management variables such as company internal processes, qualification of the rescue practitioners, and creation of enabling environment during the rescue process.

These observations are supported by work done by Chua (2009) and Jeon, Kim and Koh (2011) on the impact of knowledge management as a framework for designing a company's strategy and processes that can be used to create economic and social value to the company stakeholders.

Pretorius and Rosslyn-Smith (2014) posited that one of the key functions of business rescue is to create a medium of communication and enable transparency, which is one of the components of knowledge management. This concept is supported by Baloh, Desouza and Paquette (2011) that processes that govern strategic work must be properly mapped so as to depict what is going on in the organization and how tasks are accomplished. In terms of the role of the qualifications and skills of the business rescue practitioner, findings by Rajaram and Singh (2018) indicated the knowledge base of a practitioner should be formal and systematic. Practitioners were found to require a formal accounting qualification and have a knowledge of corporate law. Although the focus of the findings indicates the requirement for financial and legal knowledge, research on operational knowledge and qualification for the business rescue practitioners is lacking, which creates a gap in the application of knowledge management processes that are necessary for a business rescue process.

\section{Method}

A systematic review of available literature on business rescue and knowledge management was performed. Tranfield et al. (2003); Fisch and Block (2018) and Snyder (2019) have established the basis for conducting systematic literature reviews in management studies because such reviews merge empirical evidence from studies conducted and identify areas of consensus and disagreements between scholars and researchers. 
The search strategy for mapping the study consisted of search strings and sources for inclusion and exclusion criteria. The search string was applied in title, abstract and keywords using "OR" and "AND" boolean operators that considered four (4) areas:

- Knowledge management,

- Business rescue in South Africa using Chapter 6 of the Companies Act of 2008,

The purpose of restricting the search to the last five years duration is to discover latest knowledge management initiatives and practices supporting the area business rescue and turnaround of distressed companies. The search string for this paper is shown in Table 1.

Table 1. Search terms of the mapping search criteria of the study

\begin{tabular}{|l|l|}
\hline Search Areas & Search Terms \\
\hline Knowledge management & "Knowledge management" OR "knowledge practices" \\
\hline $\begin{array}{l}\text { Business rescue Chapter 6 of the Companies } \\
\text { Act of 2008 }\end{array}$ & $\begin{array}{l}\text { "Business rescue" AND "bankruptcy" OR "South Africa" OR } \\
\text { "insolvency" }\end{array}$ \\
\hline
\end{tabular}

A phased approach was applied to collect material from scholarly databases. The following list of online databases were used in the search process are:
(i) JSTOR online library
(ii) Science Direct
(iii) Emerald insight
(iv) Wiley online library

The literature review comprised of English-based peer-reviewed articles, present in Science Direct, JSTOR, Emerald, and Wiley online libraries database, the following terms that are shown in Table 1. The selection criteria of the articles consist of one (1) inclusion criteria and five (5) exclusion criteria that are shown in Table 2.

Table 2. Search inclusion and exclusion criteria of the study

\begin{tabular}{|l|l|}
\hline Criteria & Description \\
\hline Inclusion criteria & $\begin{array}{l}\text { The article discusses knowledge management in business } \\
\text { rescue or turnaround insolvency }\end{array}$ \\
\hline \multirow{3}{*}{ Exclusion criteria } & The article does not have an abstract \\
\cline { 2 - 2 } & The article is published as an abstract only \\
\cline { 2 - 2 } & The article is not written in English \\
\cline { 2 - 2 } & The article was published before 2017 \\
\cline { 2 - 2 } & The article is not based on a primary study \\
\hline
\end{tabular}

The initial outcome of the search resulted in 1961 articles were retrieved from the online scholarly databases. The outcomes are illustrated in Figure 1, which indicate that Wiley had the most articles on all the search terms.

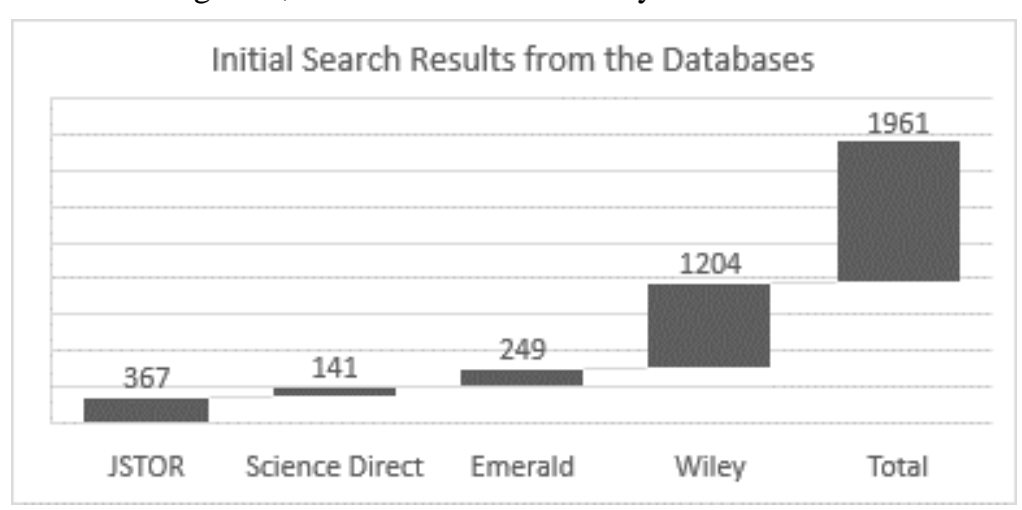

Figure 1. Initial search outcomes from databases 
Five exclusion criteria were applied to the results of the initial databases search. The first and second exclusion criteria allowed the researcher to select papers that were published in English and between 2017 and 2021. This criterion allowed the researcher to attain papers that have the most recent research on knowledge management practices in business rescue. The third and fourth criteria applied was on the removing papers that were not primary studies and didn't have abstracts. The final and fifth criteria was applied whereby the researcher read the paper abstracts to check the relevance of the paper to the research objective of the study. The outcome of the exclusion criteria resulted in 12 papers, which are indicated in Figure 2.

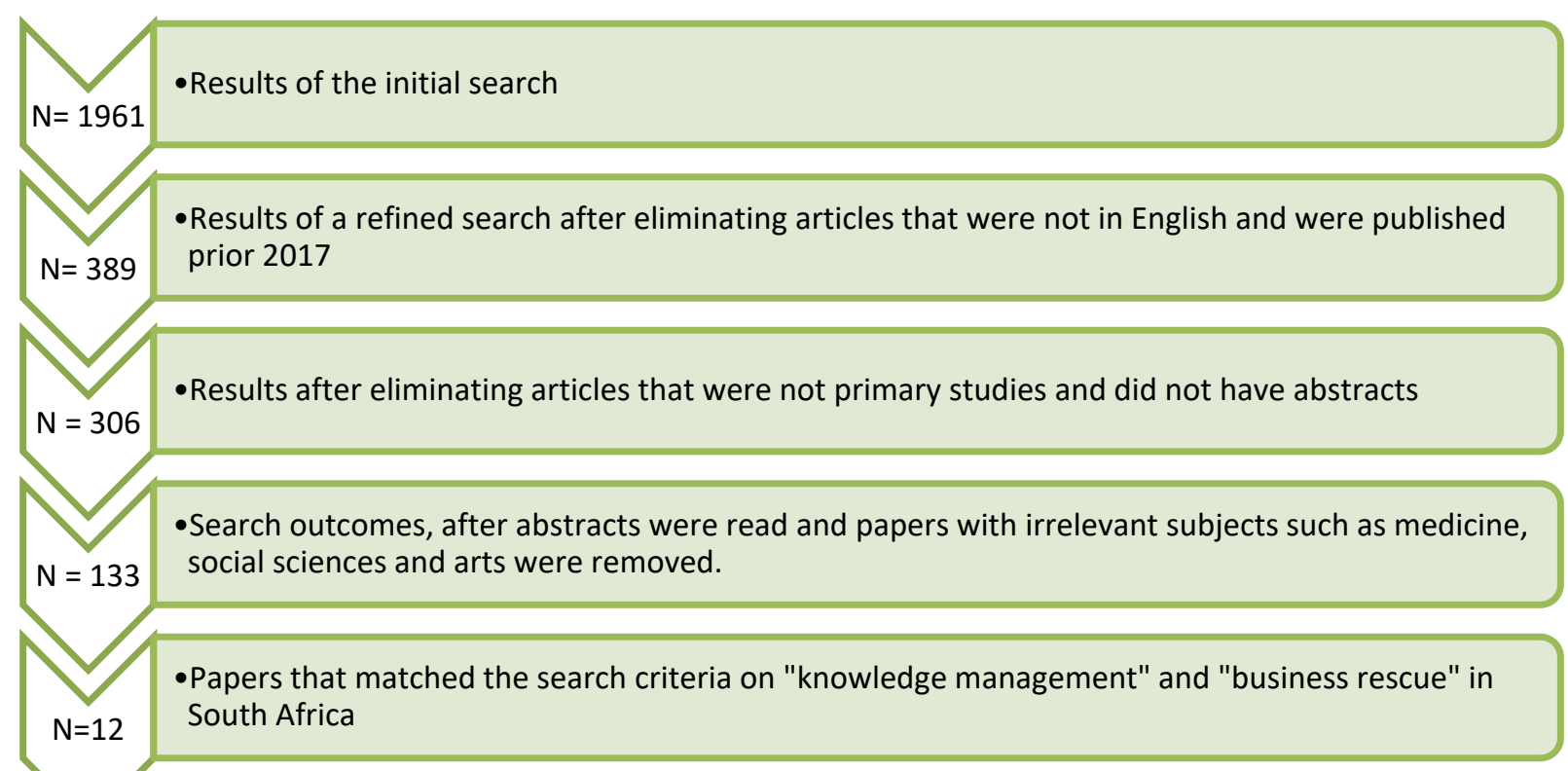

Figure 2. Final search outcomes after application of elimination criteria

\section{Results}

A descriptive analysis of the search findings was done on the 133 papers found on knowledge management and business rescue and the 12 papers that were specific to South Africa. Three areas that were descriptively analysed were:

(i) Number of papers published per year between 2017 and 2021,

(ii) Research methodology per paper, and

(iii) Number of publications per journal.

Figure 3 presents the number of papers published per year between 2017 and 2021 on business rescue and knowledge management, which were not exclusively about the practices in South Africa. Figure 2 shows that most of the papers were published in 2017, with the highest number of works of 39 papers during 2017. The stable and consistent average papers of 23.5 papers per year between 2018 and 2021, is an indication that global interest on knowledge management and business rescue has not significantly grown. 


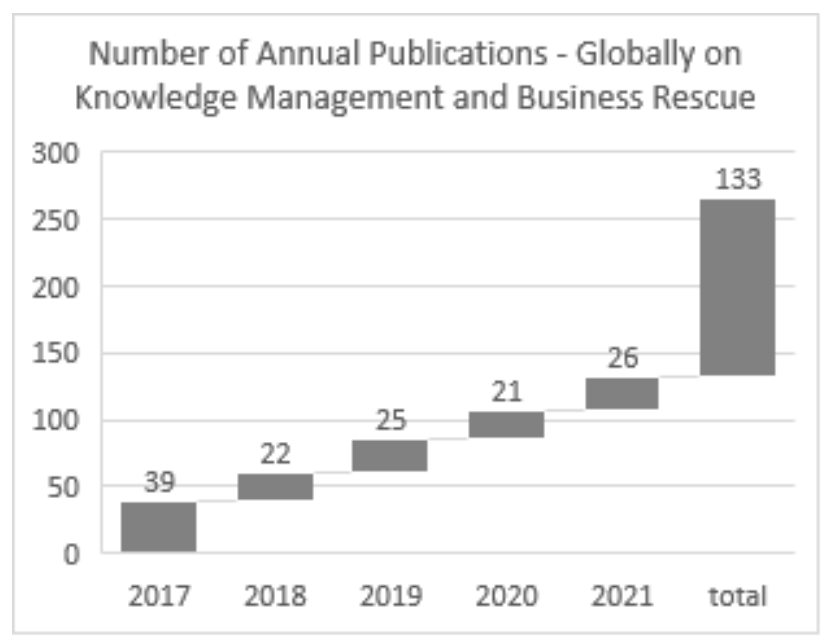

Figure 3. Number of papers published globally per year between 2017 and 2021

Figure 4 illustrates that a total of 12 papers were found to match the keywords of the refines search on knowledge management, business rescue and South Africa, which is a significant reduction of the 133 papers published globally in the same study areas. Highest number of 6 papers were published in 2018, as shown in figure 4. The interest and number of published papers has since declined from 2019 till 2020, which is an indication that new information is not being generated in these study areas.

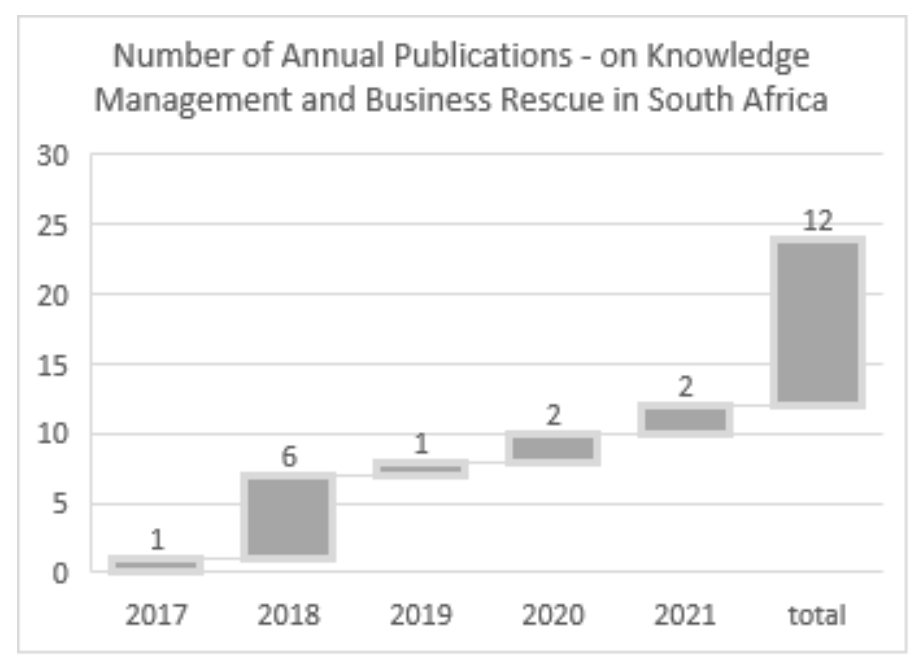

Figure 4. Number of papers published about South Africa per year between 2017 and 2021

Figure 5 depicts the distribution of papers on South Africa, knowledge management and business rescue per methodology used. Majority of the paper used qualitative research to gather primary data from business rescue practitioners and executives who are responsible for implementing knowledge management in South African distressed companies. 


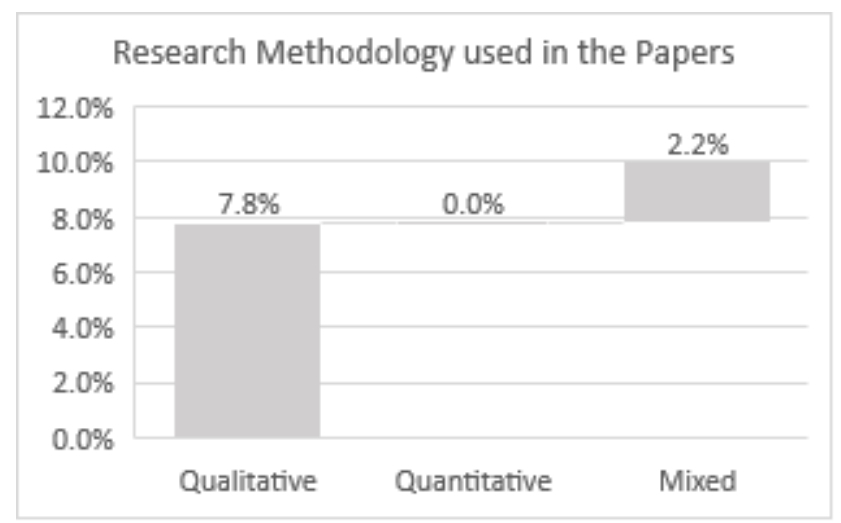

Figure 5. Research methodology used in the papers published about South Africa per year between 2017 and 2021

Table 3 and 4 presents a frequency of articles published per journal per year. Table 3 shows the number of articles published on South African business rescue and knowledge management. Data indicates that there is no journal that consistently publishes relevant paper on this subject on a yearly basis. Globally, the International Insolvency Review Journal has consistently published the highest number of papers, as indicated in Table 4.

Table 3. Number of papers published on South African business rescue and knowledge management

\begin{tabular}{|c|c|c|c|c|c|}
\hline Journal Name & $\mathbf{2 0 1 7}$ & $\mathbf{2 0 1 8}$ & $\mathbf{2 0 1 9}$ & $\mathbf{2 0 2 0}$ & $\mathbf{2 0 2 1}$ \\
\hline Journal of Economic and Financial Sciences & 0 & 1 & 0 & 1 & 0 \\
\hline Corporate Board: Role Responsibilities and Composition & 1 & 1 & 0 & 0 & 0 \\
\hline South African Journal of Accounting Research & 0 & 1 & 1 & 0 & 0 \\
\hline Acta Commercii - Independent Research Journal in the & 0 & 0 & 0 & 0 & 1 \\
Management Sciences & & & & & \\
\hline South African Journal of Economic and Management Sciences & 0 & 3 & 0 & 0 & 1 \\
\hline South African Journal of Business Management & 0 & 0 & 0 & 1 & 0 \\
\hline
\end{tabular}

As illustrated in table 4, other than the International Insolvency Review Journal, there are no academic journals with a notoriously high concentration of papers. However, despite the lack of annual homogeneity of the business rescue and knowledge management research publications, it is possible to identify that the stable growth in research paper production.

Table 4. Number of papers published on business rescue and knowledge management globally

\begin{tabular}{|c|c|c|c|c|c|}
\hline Wiley Journals & 2017 & 2018 & 2019 & 2020 & 2021 \\
\hline International Insolvency Review & 9 & 7 & 7 & 6 & 4 \\
\hline $\begin{array}{c}\text { African Research Bulletin: Economic Financial \& Technical } \\
\text { Series }\end{array}$ & 5 & 0 & 2 & 1 & 0 \\
\hline Modern Law Review & 2 & 0 & 0 & 0 & 0 \\
\hline European Law Journal & 1 & 0 & 0 & 0 & 0 \\
\hline Financial markets, institutions, and instruments & 1 & 0 & 1 & 0 & 0 \\
\hline Journal of Risk and Insurance & 1 & 0 & 0 & 0 & 0 \\
\hline Parliamentary History & 1 & 0 & 0 & 0 & 0 \\
\hline Regulation \& Governance & 1 & 0 & 0 & 0 & 0 \\
\hline Antipode & 0 & 1 & 0 & 0 & 0 \\
\hline Economic Affairs & 0 & 1 & 0 & 0 & 0 \\
\hline Financial Management & 0 & 1 & 0 & 0 & 0 \\
\hline German Economic Review & 0 & 1 & 0 & 0 & 0 \\
\hline Journal of Applied Econometrics & 0 & 1 & 0 & 0 & 0 \\
\hline The British Journal of Sociology & 0 & 1 & 0 & 0 & 0 \\
\hline The Modern Law Review & 0 & 1 & 0 & 0 & 0 \\
\hline American Business Law Journal & 0 & 0 & 2 & 1 & 0 \\
\hline Asian Economic Policy & 0 & 0 & 1 & 0 & 0 \\
\hline
\end{tabular}


Contemporary Accounting Research

Journal of the Royal Anthropological Institute

Journal of Applied Corporate Finance Journal of Future Markets

Journal of Money, Credit and Banking Mathematical Finance

Journal of Applied Social Psychology Middle East Policy

$\begin{array}{lllll}0 & 0 & 1 & 1 & 0 \\ 0 & 0 & 1 & 0 & 0 \\ 0 & 0 & 0 & 1 & 0 \\ 0 & 0 & 0 & 1 & 0 \\ 0 & 0 & 0 & 1 & 1 \\ 0 & 0 & 0 & 1 & 0 \\ 0 & 0 & 0 & 0 & 1 \\ 0 & 0 & 0 & 0 & 1\end{array}$

\begin{tabular}{|c|c|c|c|c|c|}
\hline Emerald Journals & 2017 & 2018 & 2019 & 2020 & 2021 \\
\hline Journal of Financial Regulation and Compliance & 1 & 0 & 0 & 0 & 0 \\
\hline International Journal of Law and Management & 0 & 2 & 0 & 0 & 0 \\
\hline Journal of Management History & 0 & 1 & 0 & 0 & 0 \\
\hline International Journal of Managerial Finance & 0 & 0 & 1 & 0 & 0 \\
\hline Management Research Review & 0 & 0 & 1 & 0 & 0 \\
\hline Accounting, Auditing and Accountability Journal & 0 & 0 & 1 & 0 & 1 \\
\hline Qualitative Research in Financial Markets & 0 & 0 & 0 & 0 & 1 \\
\hline International Journal of Social Economics & 0 & 0 & 0 & 0 & 1 \\
\hline Journal of Economic and Administrative Sciences & 0 & 0 & 0 & 0 & 1 \\
\hline Science Direct Journals & 2017 & 2018 & 2019 & 2020 & 2021 \\
\hline Journal of economic dynamics and control & 1 & 0 & 0 & 0 & 0 \\
\hline Decision Support Systems & 1 & 0 & 0 & 0 & 0 \\
\hline European Journal of Operational Research & 1 & 0 & 0 & 0 & 0 \\
\hline Journal of Cleaner Production & 1 & 0 & 0 & 0 & 0 \\
\hline Journal of Financial Intermediation & 1 & 0 & 0 & 1 & 0 \\
\hline The British Accounting Review & 1 & 0 & 0 & 0 & 0 \\
\hline Journal of Macroeconomics & 1 & 0 & 0 & 0 & 0 \\
\hline The Spanish Review of Financial Economy & 1 & 0 & 0 & 0 & 0 \\
\hline Japan and the World & 0 & 1 & 0 & 0 & 0 \\
\hline Journal of Corporate Finance & 0 & 1 & 1 & 1 & 1 \\
\hline International Review of Financial Analysis & 0 & 1 & 0 & 0 & 0 \\
\hline Research in Transportation Economics & 0 & 1 & 0 & 0 & 0 \\
\hline Journal of Financial Economics & 0 & 0 & 1 & 0 & 0 \\
\hline Journal of Business Research & 0 & 0 & 1 & 0 & 2 \\
\hline Transport Policy & 0 & 0 & 1 & 0 & 0 \\
\hline North American Journal of Economics and Finance & 0 & 0 & 1 & 0 & 0 \\
\hline Economic Systems & 0 & 0 & 1 & 0 & 0 \\
\hline Journal of economic behavior and organization & 0 & 0 & 0 & 1 & 0 \\
\hline Journal of international financial markets, institutions and money & 0 & 0 & 0 & 1 & 1 \\
\hline Pacific-Basin Finance Journal & 0 & 0 & 0 & 1 & 0 \\
\hline Quarterly Review of Economics and Finance & 0 & 0 & 0 & 1 & 0 \\
\hline International Review of Law and Economics & 0 & 0 & 0 & 0 & 2 \\
\hline Journal of Financial Stability & 0 & 0 & 0 & 0 & 3 \\
\hline Physica, Statistical Mechanics and Its Application & 0 & 0 & 0 & 0 & 1 \\
\hline Economic Modelling & 0 & 0 & 0 & 0 & 1 \\
\hline Annals of Tourism Research & 0 & 0 & 0 & 0 & 1 \\
\hline International Review of Economics and Finance & 0 & 0 & 0 & 0 & 1 \\
\hline Journal of Comparative Economics & 0 & 0 & 0 & 0 & 1 \\
\hline Heliyon & 0 & 0 & 0 & 0 & 1 \\
\hline JSTOR Journals & 2017 & 2018 & 2019 & 2020 & 2021 \\
\hline Journal of Economic Perspectives & 2 & 0 & 0 & 1 & 0 \\
\hline Journal of Business Ethics & 1 & 0 & 0 & 0 & 0 \\
\hline Columbia Law Review & 1 & 0 & 0 & 1 & 0 \\
\hline University of Chicago Law Review & 1 & 0 & 0 & 0 & 0 \\
\hline World Review of Political Economy & 2 & 1 & 1 & 0 & 0 \\
\hline National Tax Journal & 1 & 0 & 0 & 0 & 0 \\
\hline Harvard Law Review & 1 & 0 & 0 & 0 & 0 \\
\hline
\end{tabular}

A thematic analysis of the search findings was done on the papers found on knowledge management and business rescue in South Africa. Thematic analysis was conducted to classify and present themes found in the papers during the review. Guest, Namey and Chen (2020) state that thematic analysis offers an opportunity to understand issues arising from research more widely. 


\section{Knowledge Management Themes Found During Review}

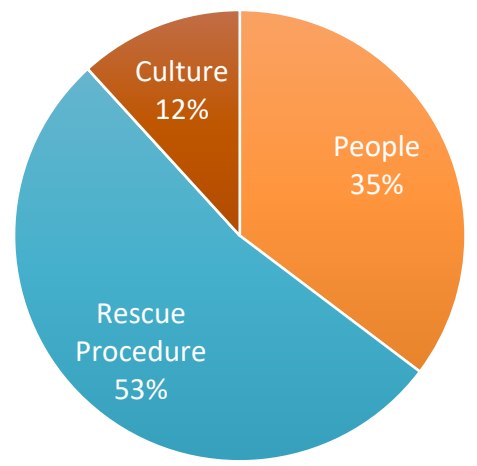

- People $\quad$ Rescue Procedure $\quad$ Technology \& Innovation $\quad$ Culture

Figure 6. Themes found in the papers published about South Africa business rescue and knowledge management

As illustrated in figures 6, three main knowledge management themes emerged which were: culture, people and procedure. Data in figure 6 indicates that $53 \%$ of the papers focused on the "procedure" theme which specifically focused on the business rescue procedure that is outlined in the Companies Act No.71 of 2008 . There were not findings that indicated that there is lack of research interest in technology and innovation pillar of knowledge management in the business rescue process.

\section{Discussion}

The systematic literature review revealed two main insights on business rescue in South Africa. First, business rescue is a relatively new concept that is rooted in past legislation on insolvency. The business rescue Act was promulgated in 2008 and therefore not surprising that there was very little peer-reviewed research on the subject. Researchers were found to be optimistic about the theoretical application of the business rescue process, and positive perceptions of its impact from the qualitative studies that were conducted.

Secondly, the review indicated that there is interest to research the link between knowledge management and business rescue. This suggest that the application and integration knowledge management pillars (i.e. people, procedure, technology and innovation) into business rescue practices is yet to mature in South Africa. The analysis indicates that there is a need to strengthen the process of developing gatekeepers of how innovation, technologies and procedures are implemented and shared between business rescue practitioners and executives on an organizational level, and an industry level.

Thirdly, studies by Pretorius (2013), Conradie and Lamprecht (2015), and Naidoo, Patel, and Padia (2018) documented the need for performance indicators that will measure the financial and operational performance of the companies, pre, and post-rescue process. The effectiveness of business rescue strategies can only be measured when the key business performance indicators are measured before the decline and distress of the company and after the implementation of the business rescue strategy.

This finding is in line with Section 128(f) of Chapter 6 of the South African Companies Act No. 71 of 2008, which describes financial distress as 'the reasonable likelihood that a company will be unable to pay its debts within the immediate six months or is almost certain to become insolvent within the immediate six months.

Findings from the articles by Rosslyn-Smith, de Abreu and Pretorius (2019), Lusinga and Fairhurst (2020); and Ramnamum, Pillay and Rajaram (2020) indicate that financial and stakeholder relations decisions made by the business rescue practitioner determine the future capital structure of the company, once it emerges from business rescue process. These studies asserted the experience and reputation of the business rescue practitioner in undertaking managerial and fiduciary responsibilities that can either strengthen the company's balance sheet or lead to liquidation. These responsibilities are stated in Chapter 6 of the Companies Act No. 71 of 2008, which requires a business rescue practitioner to consider whether there is any reasonable prospect of the company being 
rescued. The management of the company's business activities is therefore placed under the temporary supervision of the business rescue practitioner.

Currently, other than the directives in Chapter 6 of the Companies Act of 2008, literature findings do not indicate a preferred business rescue model for companies that is appropriate for application within the constraints of the Companies Act. Section 128(b) of this legislation generically describes the business rescue process as "proceedings to facilitate the rehabilitation of a company that is financially distressed" by providing for:

(i) The temporary supervision of the company and the management of its affairs, business and property,

(ii) A temporary moratorium on the rights of claimants against the company or in respect of property in its possession; and

(iii) The development and implementation, if approved, of a plan to rescue the company by restructuring its affairs, business, property, equity, debt, and other liabilities in a manner that maximizes the likelihood of the company continuing in existence on a solvent basis or; if it is not possible for the company to so continuing in existence, results in a better return for the company's creditors or shareholders that would result from the immediate liquidation of the company".

Despite the findings made from the systematic literature review, one of the challenges from literature was the lack of longitudinal research data, as literature was mainly based on cross-sectional data. Rajulton (2001) and Setia (2016) state that cross-sectional data is usually collected at one point in time, as a snapshot view of the issue being studied at a particular time. In the literature analyzed, cross-sectional data was recorded in most of the studies in form of surveys, with a new sample on each occasion.

The limitations of repeated cross-sectional data are its inappropriateness for studying developmental patterns within cohorts and its inability to resolve issues of causal order (Zheng, 2015). These limitations are caused by the fact that in a repeated cross-sectional design, the same cases are neither measured repeatedly nor for multiple periods (Setia, 2016). For instance, most of the literature mentions the responsibilities and activities of the business rescue practitioner whereby data was collected through a cross-sectional qualitative research design. Based on the findings, it is difficult to determine whether the learning from previous studies was incorporated into new generation studies or used to develop practice notes which could be annexed to the Companies Act No. 71 of 2008. The accomplishment of such work would require future studies to have a combination of longitudinal and cross-sectional data designs. Rajulton (2001) posited that longitudinal research focuses on 'how people change' and the people's response to change. Although this approach has been more widely used in quantitative social studies to measure the objective aspects of change through dimensions such as time, it is recommended for future studies on the business rescue process.

\subsection{Implications}

Based on the preceding literature review on business rescue and incorporation of knowledge management, several implications on theory and practice can be identified.

The review led the researcher to conclude that some patterns on the adoption of knowledge management in business rescue process can be observed. The pattern that was observed was on the extent to which different aspects of knowledge management are implemented during the rescue process.

The review indicated that there is less focus on defining the culture of how business rescue is done. Emphasis on culture in institutions and industry organisations can be regarded as a form of tacit knowledge that Harlow (2008) and Peet (2012) describes as a code of how things are done and is internal to the institution.

Business rescue practitioners are often unaware of the knowledge they possess or are incapable of expressing something that for them in natural and obvious. Adopting tacit knowledge as a requirement for practitioners by industry organisations can be one of the ways of transferring tacit knowledge and preventing the loss of this knowledge through turnover or death of practitioners.

Another pattern that was observed was that knowledge management within business rescue processes is seen as a combination of people, procedure and technological interactions. This interaction is part of the process-oriented approach in knowledge management as discussed by Nonaka and Takechi (1995). The process-oriented knowledge management approach focuses on both tacit and explicit knowledge. Research by Jelavic (2011) indicated that a process approach in knowledge management was key in organisations and industry institutions degree of adopting and adapting of current and new knowledge management practices for long-term sustainability.

This study therefore contributes towards extending literature on knowledge management in the business rescue 
fraternity. The results of this study provide business rescue practitioners and managers with insights into how to incorporate or improve their organizational effectiveness when implementing business rescue.

\section{Conclusion}

The research on the business rescue process has not significantly accumulated since 2008 , and literature has remained disjointed resulting in an increasing number of business rescue cases being unresolved year on year.

The business rescue law was designed to alleviate the challenges facing distressed companies. For this purpose, a systematic review of academic literature on the business rescue process and the integration of knowledge management in the process was conducted. The literature analysis highlighted; the lack of longitudinal research data which can be used to develop practice notes and guidelines for the business rescue practitioners; and finally, that the business rescue process is currently underpinned by knowledge management concepts that have little academic research to support it. Based on the literature analysis, it is clear that more research is needed in the application and knowledge management of the business rescue directives in the Companies Act No.71 of 2008.

\section{References}

Aviazian, V., \& Zhou, S. (2012). Is Chapter 11 Efficient? Financial Management Journal, 4(1). https://doi.org/10.1111/j.1755-053X.2012.01196.x

Baloh, P., Desouza, K., \& Paquette, S. (2011). The Concept of Knowledge Management: Introduction. New York, Neal-Schuman Publishers.

Beuthin, R., \& Luiz, S. (2000). Winding Up. Beuthin's Basic Company Law (3rd ed.). Durban: Butterworth Publisher.

Bhatt, G. (2001). Knowledge Management in Organisations: Examining the Interaction between Technologies, Techniques and People. Journal of Knowledge Management, 5(1). https://doi.org/10.1108/13673270110384419

Byukusenge, E., \& Munene, E. (2017). Knowledge Management and Business Performance: Does Innovation Matter? Cogent Business and Management, 4(1). https://doi.org/10.1080/23311975.2017.1368434

Calitz, A., \& Cullen. M. (2017). The Application of a Knowledge Management Framework to Automotive Original Component Manufacturer. Interdisciplinary Journal of Information Knowledge and Management, 12. https://doi.org/10.28945/3897

Chua, A. (2009). The Dark side of Successful Knowledge Management Initiatives. Journal of Knowledge Management, 13(4). https://doi.org/10.1108/13673270910971806

Conradie, S., \& Lamprecht, C. (2015). Business Rescue: How can its Success be Evaluated at Company Level. South African Business Review Journal, 19(3).

De Abreu, N., \& Rosslyn-Smith, W. (2021). Investigating the Direct Costs of Business rescue. Acta Commercii, 21(1). https://doi.org/10.4102/ac.v21i1.903

de Clercq, B., Evans, R., Abrie, W., \& Graham, C. (2011). Schedule 1: Insolvent Act no 24 of 1936. Insolvent Estates. Pretoria: Government Printers.

Fair, D., \& Raymond, R. (1993). The New Europe: The Evolving Economic and Financial Systems in The East and West: Springer Science. https://doi.org/10.1007/978-94-011-1741-8

Finch, B. (2012). Insolvency and Financial Distress: How to Avoid It and Survive It. New York. Bloomsbury.

Fisch, C., \& Block, J. (2018). Six Tips for your Systematic Literature Review in Business and Management Research. Management Review Quarterly Journal, 68. https://doi.org/10.1007/s11301-018-0142-x

Guest, G., Namey, E., \& Chen, M. (2020). A Simple Method to Assess and Report Thematic Saturation in Qualitative Research. PLOS One online Journal, 15(5). https://doi.org/10.1371/journal.pone.0232076

Harlow, H. (2008). The Effect of Tacit Knowledge on Firm Performance. Journal of Knowledge Management, 56(2), 145-152. https://doi.org/10.1108/13673270810852458

Harrington, H. (2005). The Five Pillars of Organisational Excellence. Handbook of Business Strategy, 6(1), 107-114. https://doi.org/10.1108/08944310510557116

Jeon, S., Kim, Y., \& Koh, J. (2011). An Integrative Model for Knowledge Sharing in Communities of Practice. Journal of Knowledge Management, 15(2). https://doi.org/10.1108/13673271111119682

Lamprecht, C., \& Van Wyk, H. (2020). Context-Specific Indicators to Guide the Judgement of a Going Concern 
for a Company in Business Rescue. Journal of Economic and Financial Sciences, 13(1). https://doi.org/10.4102/jef.v13i1.483

Le Roux, A., \& Pretorius, M. (2017). Exploring Entrepreneurial Learning During Formal Business Rescue Processes: Insight from The South African Experience. South African Journal of Human Resources 2017.

Lebeloane, V. (2017). An Evaluation of Business Rescue Plans Based on Business Rescue Principles and Guidelines to Determine Leading Indicators of Business Rescue Outcomes. Pretoria, University of Pretoria

Lusinga, D., \& Fairhurst, K. (2020). Role of Stakeholders in Business Rescue. South African Journal of Business Management, 51(1). https://doi.org/10.4102/sajbm.v51i1.1957

Mpofu, K., Nwafor, A., \& Selala, K. (2018). Exploring the Role of the Business Rescue Practitioner in Rescuing a Financially Distressed Company. Journal of Corporate Board: Role, Duties and Composition, 14(2). https://doi.org/10.22495/cbv14i2art2

Naidoo, T., Patel, A., \& Padia, N (2018). Business Rescue Practices in South Africa. Journal of Economic and Financial Services, 11(1). https://doi.org/10.4102/jef.v11i1.188

Newton, N. (2009). Bankruptcy and Insolvency Accounting: Practice and Procedure (7th ed.). Hoboken, John Wiley \& Sons.

Ngobeni, M. (2016). Critical Analysis of Section 153 (I) (A) (II) In Whose Interest Do Creditors Act During Business Rescue Proceedings, Pretoria, University of Pretoria.

Nwafor, A. (2017). Moratorium in Business Rescue Scheme and the Protection of Company's Creditors. Journal of Corporate Board: Role, Duties and Composition, 13(1). https://doi.org/10.22495/cbv13i1p6

Paul, J. (2010). Business Environment: Text and Cases. New Delhi: Tata McGraw Hill.

Peet, M. (2012). Leadership Transitions Tacit Knowledge Sharing and Organizational Generativity. Journal of Knowledge Management, 16(2012), 45-60. https://doi.org/10.1108/13673271211198936

Pretorius, J. (2008). Companies Act 61 of 1973. Companies Act of 1973 and Close Corporation Act of 1984. Pretoria: Juta.

Pretorius, J., Delport, P., Havenga, M., \& Vermaas, M. (1991). Winding-up: Judicial Management: Corporate Delinquents. (5th ed.) Hahlo's South African Company Law through the Cases: A Source Book. Cape Town: Juta \& Co.

Pretorius, M. (2008). Critical Variables of Business Failure: A Review and Classification Framework, Pretoria: University of Pretoria.

Pretorius, M. (2013). Tasks and Activities of The Business Rescue Practitioners: A Strategy as Practice Approach. South African Business Review Journal, 17(3).

Pretorius, M., \& Rosslyn-Smith, W. (2014). Expectations of Business Rescue Plan: International Directives for Chapter 6 Implementation. South African Business Review Journal, 18(2). https://doi.org/10.25159/1998-8125/5681

Rajaram, R., \& Singh, A. (2018). Competencies for Effective Management of Legislated Business Rehabilitations. South African Journal of Economics and Management Sciences, 21(1). https://doi.org/10.4102/sajems.v21i1.1978

Rajulton, F. (2001). Special Issue on Longitudinal Methodology. Canadian Studies on Population, 28(2). https://doi.org/10.25336/P6W897

Ramnamum, K., Pillay, S., \& Rajaram, R. (2019). Ascertaining the Impact of Post-Commencement Finance on Business Rescue in Kwazulu Natal. Academy of Accounting and Financial Studies Journal, 24(6).

Rosslyn-Smith, W., de Abreu, N., \& Pretorius, M. (2020). Exploring the Indirect Costs of a Firm in Business Rescue. South African Journal of Accounting Research, 34(1). https://doi.org/10.1080/10291954.2019.1667647

Setia, M. (2016). Methodology Series Module: Cross-Sectional Studies. Indian Journal of Dermatology, 61(3). https://doi.org/10.4103/0019-5154.182410

Shein, J. (2011). Reversing the Slide: A Strategic Guide to Turnaround and Corporate Renewal. London: John Wiley and Sons.

Snyder, H. (2019). Literature Review as a Research Methodology: An Overview and Guidelines. Journal of 
Business Research 104(4). https://doi.org/10.1016/j.jbusres.2019.07.039

Tranfield, D., Denyer, D., \& Smart, P. (2003). Towards a Methodology for Developing Evidence-Informed Management Knowledge by Means of Systematic Review. British Journal of Management, 14. https://doi.org/10.1111/1467-8551.00375

Walton, P., Umfreville, C., \& Jacobs, L. (2020). A Snapshot of Company Voluntary Arrangements: Success, Failure and Proposal for Reform. International Insolvency Review Journal, 29(2). https://doi.org/10.1002/iir.1381

Wood, P. (2007). Principles of International Solvency. New York. Sweet and Maxwell.

Zheng, M. (2015). Conceptualization of Cross-Sectional Mixed Methods Studies in Health Sciences: A Methodology Review. International Journal of Quantitative and Qualitative Research Methods, 3(2).

\section{Copyrights}

Copyright for this article is retained by the author(s), with first publication rights granted to the journal.

This is an open-access article distributed under the terms and conditions of the Creative Commons Attribution license (http://creativecommons.org/licenses/by/4.0/). 